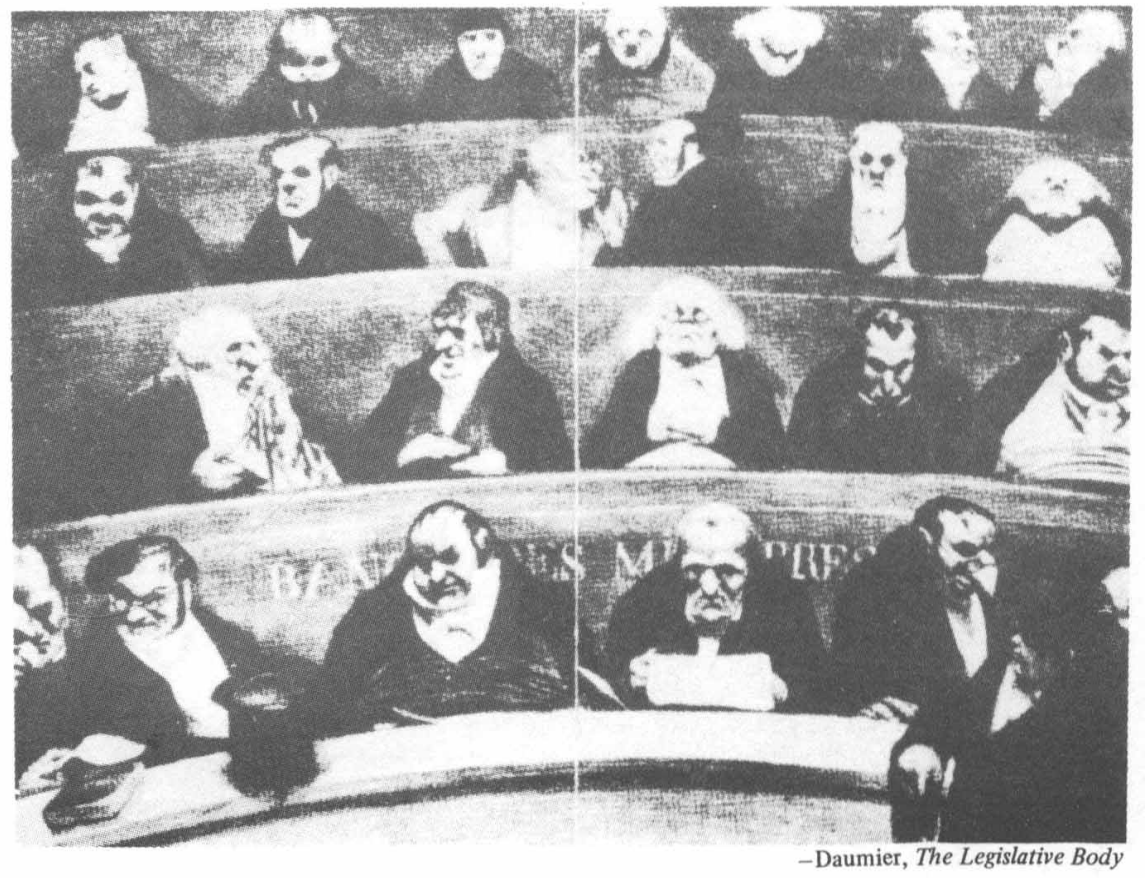

\title{
STUDIES IN THE HISTORY OF PARLIAMENTS
}

JOHN BELL HENNEMAN Representative Assemblies and the Historians

ThOMas N. BISSON Celebration and Persuasion: Reflections on the Cultural Evolution of Medieval Consultation

CONRAD S. R. RUSSELL War and Estates, 1500-1648

ESTHER S. COPE Public Images of Parliament During its Absence

JOHN H. GREVER Louis XIV and the Dutch Assemblies: The Conflict about the Hague

MICHAEL F. METCALF Radical Thought in Eighteenth-Century Sweden: The Challenge to Economic Orthodoxy and Parliamentary Sovereignty, $1755-1772$

VIVIAN R. GRUDER No Taxation Without Representation: The Assembly of Notables of 1787 and the Formation of Political Ideology in France

VALERIE CROMWELL Mapping the Political World in 1861: A Multidimensional Analysis of House of Commons' Division Lists

\section{special Issue of Legislative Studies Quarterly}

Address orders to 304 Schaeffer Hall, The University of Iowa, Iowa City, Iowa 52242 Special Issue \$9 Postpaid Annual Subscription $\$ 16.50$ 


\section{RECENTL Y PUBLISHED}

\section{CLASS CONFLICT}

\section{AND COLLECTIVE ACTION}

edited by LOUISE A. TILLY and CHARLES TILLY, University of Michigan

Published in cooperation with the Social Science History Association

The contributors to Class Conflict and Collective Action break with the predominant definition of class conflict as societal tension-release, and instead see social movements as responses to the concerns of everyday life. Studying the effects of European proletarianization and capital concentration between 1750 and 1914, the essays seek to determine at what point class conflict generated a collective action, and how the historical forms of contention changed under the influence of capitalism and nationalization. Edited by noted scholars Louise and Charles Tilly, this book forms a vital contribution to the ultimate goal of a comparative history of the Western industrial working class.

Class Conflict and Collective Action, the first volume in Sage's New Approaches to Social Science History series, integrates a body of original and innovative material, using a common intellectual framework, a comprehensive introduction and conclusion, and tight and careful editing throughout. The book will hold great interest for those studying social history, European history, labor history, and research in power structures and the politics of collective action.

CONTENTS: Preface STANLEY L. ENGERMAN / 1. Introduction CHARLES TILLY / 2. The Web of Contention in Eighteenth-Century Cities CHARLES TILLY / 3. Revolution and the Rural Community in the Eastern Netherlands WAYNE TE BRAKE / 4. Contentious Gatherings in Lancashire, England, 1750-1830 FRANK MUNGER / 5. Industrialism Capitalism, Conflict, and Working-Class Contention in Lancashire, 1842 BRIAN R. BROWN / 6. Keeping the Navvies in Line: Variations in Work Discipline Among Victorian British Railway Construction Crews SAMUEL COHN / 7. Belgian and French Workers in Nineteenth-Century Roubaix JUDY A. REARDON / 8. Grapes of Wrath: Vineyard Workers, Labor Unions, and Strike Activity in the Aude, 1860-1913 LAURA L. FRADER / 9. Women's Collective Action and Feminism in France, 1870-1914 LOUISE A. TILLY / 10. Conclusion LOUISE A. TILLY

New Approaches to Social Science History, Volume 1

1981

260 pages

\section{ISBN 0-8039-1587-X} ISBN 0-8039-1588-8

\section{hardcover} softcover
$\$ 22.50$ $\$ 9.95$
SAGE Publications, INC. 275 South Beverly Drive Beverly Hills, California 90212
SAGE Publications, LTD. 28 Banner Street London EC1Y 8QE, England 


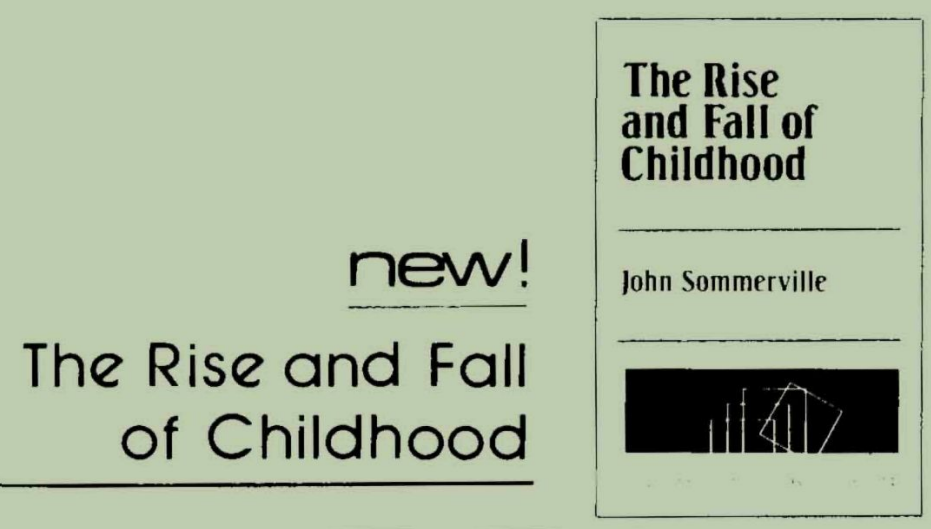

by JOHN SOMMERVILLE, Department of History, University of Florida

"Go to school. Stand before your teacher, recite your assignment. . . . Be humble and show fear before your superiors."

-A Sumerian scribe to his son, c. 1800 B.C.

Since the dawn of history, parental admonitions to children have projected certain unchanging assumptions. Yet while some tenets of child rearing have remained constant over the centuries from Sparta to Spock. Som. merville pinpoints many significant changes in adult perceptions of their offspring. This readable history of children highlights changing cultural attitudes, expectations, and fears adults have harbored about the young. Sommerville describes major transformations in the upbringing, health, education, morals, and work patterns of children and adolescents over the course of Western civilization. Illustrated with vignettes and commentaries from different historical periods, The $R$ ise and Fall of Childhood will be a useful guide and text for professionals, scholars, and students interested in social history, families, children, education, social welfare, and related areas.

CONTENTS: Introduction/1. As Other Times Might See Us/2. The Dawn of History, and Children Already a Problem / 3. Athens and Jerusalem: A Lifetime of Learning/4. Rome and the Collapse of the Trustee Family / 5. Christianity and the Reversal of Status / 6. A Dark Age and the Revival of Family Authority / 7. Civilization Begins Again / 8. Renaissance Childhood and Creativity / 9. Childhood Becomes Crucial: The Religious Reformation / 10. The Nation-State Takes Up Child Care / 11. Chi'dren and Progress: An Early Social Movement / 12. The Glorification of the Child / 13. The Business of Entertaining Children / 14. Concern for the Child's Survival / 15. The High and Low Point in the History of Childhood / 16. Growing Pains and Revolution / 17. The Standardizing of Childhood / 18. The Demythologizing of Childhood/19. The Liberation of Children /20. The Identity Crisis of Our Civilization / Notes

\section{Sage Library of Social Research, Volume 140 1982 (April) 256 pages

SAGE Publications, INC. 275 South Beverly Drive Beverly Hills, California 90212
SAGE Publications, LTD. 28 Banner Street London EC1Y $80 \mathrm{E}$, England 